\title{
Sclerostin Domain-Containing Protein 1
}

National Cancer Institute

\section{Source}

National Cancer Institute. Sclerostin Domain-Containing Protein 1. NCI Thesaurus. Code C132099.

Sclerostin domain-containing protein 1 (206 aa, $23 \mathrm{kDa}$ ) is encoded by the human SOSTDC1 gene. This protein is involved in the inhibition of bone morphogenic proteins. 